\title{
ROLE OF DNA AND BACTERIOPHAGE IN CAMPYLOBACTER AUTO-AGGLUTINATION
}

\author{
A. E. Ritchie, J. H. Bryner AND J. W. Foley \\ National Animal Disease Center, United States Department of Agriculture, \\ P.O. Box 70, Ames, Iowa 50010, USA
}

\begin{abstract}
SUmmary. Auto-agglutinated and non-agglutinated cells of Campylobacter jejuni and $C$. coli were examined by transmission electronmicroscopy in phosphotungstate negative stain. Agglutination was induced by three factors (1) extracellular DNA, (2) an aggregated protein, probably a bacteriophage precursor, and (3) free phage-tail sheaths. Auto-agglutinated cells were often "leaky," with a mantle of adhering DNA. About $80 \%$ of the auto-agglutinated cells could be resuspended after treatment with DNAase. Flagella were loosely embedded in protein aggregates, especially in phage-infected cultures. They were clumped in a side-by-side arrangement by free phage-tail sheaths. These findings suggest that auto-agglutination could be minimised in suspensions of organisms intended for use in agglutination tests by harvesting early logarithmic-phase cells containing no more than a low phage population. The most common $C$. jejuni phage had a contractile tail, a head diameter of $60-70 \mathrm{~nm}$, and an overall length of $180-210 \mathrm{~nm}$. A phage isolated from $C$. jejuni strain 1590 was morphologically identical with $C$. coli phage.
\end{abstract}

\section{INTRODUCTION}

Auto-agglutination interferes with the serotyping of some Campylobacter jejuni isolates in simple tube tests (Butzler, 1978). Its cause has not been studied, but various practical means have been used to circumvent the problem, e.g., the use of (1) "stable" comma-shaped cells obtained by differential centrifugation (Lussier, 1962), (2) autoclaved cells (Berg, Jutila and Firehammer, 1971), (3) alternative tests such as line-rocket immunoelectrophoresis (R-LIE) or co-agglutination with antibody-coated reagent staphylococci (COA; Kosunen, Danielsson and Kjellander, 1980), and (4) cells preincubated with DNAase (Lior et al., 1982). Our objective was to determine the cause of auto-agglutination by examining whole cells by transmission electronmicroscopy. Because our preliminary observations implicated a bacteriophage component or precursor (Ritchie, Bryner and Foley, 1982), we compared the morphology of representative phages from $C$. jejuni and $C$. coli. 


\section{MATERIALS AND METHODS}

Bacterial strains. The nomenclature used is that recommended by Skerman, McGowan and Sneath (1980). C. jejuni strains 657, 917 and 958 were isolated from aborted ovine fetuses, strains 1398,1425 and 1460 from cases of human enteritis, and strains 1590 and 1591 from rabbit faeces. C. coli strains 425,1380 and 1491 were isolated from a porcine kidney, an aborted porcine fetus, and porcine faeces, respectively. Cells were grown at 37 or $43^{\circ} \mathrm{C}$ on Mueller Hinton Agar (MH; Difco Laboratories, Detroit, $\mathrm{MI}$ ) in $\mathrm{O}_{2} 5 \%, \mathrm{CO}_{2} 10 \%$ and $\mathrm{N}_{2} 85 \%$ for $18 \mathrm{~h}$ or more (Bryner, Ritchie and Foley, 1982). When needed, larger cell masses were grown in shaker cultures of Albimi Brucella Broth (Difco Laboratories) as previously described (Bryner, Frank and O'Berry, 1962). Inocula for shaker cultures were from $\mathrm{MH}$ plates.

Electronmicroscopy and specimen treatment. For negative staining in neutralised phosphotungstate (PTA), the method of Brenner and Horne (1959) as modified by Ritchie and Fernelius (1969) was used. To minimise the physical disturbance of any structure that might be responsible for adherence of the bacteria to each other, each sample was applied to a carbon-collodion grid with a 5-mm platinum loop instead of a nebuliser. For this manipulation, the grid was placed on an absorbent paper towel and the charged loop was applied in a single motion so that the material spread evenly and absorption was uniform from the grid edge. Direct immuno-electronmicroscopy (DIEM) was done by incubating suspensions of bacteria and their phages with excess antiserum overnight at $4^{\circ} \mathrm{C}$, centrifuging at $7000 \mathrm{~g}$ for $30 \mathrm{~min}$, resuspending the pellets in distilled water, and staining negatively with PTA. Enzymic digestion of shaker cultures was done with DNAase (ICN Nutritional Biochemicals, Cleveland, $\mathrm{OH}$ ) $10-20 \mu \mathrm{g} / \mathrm{ml}$ at $37^{\circ} \mathrm{C}$ for $1-4 \mathrm{~h}$.

\section{RESULTS}

Early logarithmic-phase, non-agglutinating cultures contained turgid cells with rugose surfaces (fig. 1). Ultrastructurally, both $C$. jejuni and $C$. coli resembled $C$. fetus (Werner, Levy and Spurlock, 1961; Ritchie, Keeler and Bryner, 1966) and recently examined isolates of $C$. jejuni from man (Pead, 1979). No surface appendages other than flagella were present, nor were the flagella sheathed.

When auto-agglutinated cells, usually from 48 -h cultures, were examined, $>40 \%$ were seen to be either "leaky" or disrupted. Leakiness was indicated by a flaccid appearance and some internal staining by the PTA. Most leaky cells had a closely



FIG. 1-Campylobacter jejuni strain 657. Typical non-agglutinating logarithmic-phase cells with rugose surface and non-sheathed flagella; no other surface appendages are present. Electronmicrograph (EM). 
adhering mantle of an amorphous, streaming material (fig. 2). This could be removed by treatment with DNAase (fig. 3). DNAase did not, however, completely reverse auto-agglutination: $c$. $20 \%$ of the agglutinated cells of strain 958 could not be permanently resuspended after DNAase digestion. Ruptured cells often released masses of an aggregated protein that were generally associated with agglutinated flagella or flagellate cells (figs. 4 and 5). This substance was plentiful only in phage-bearing cultures. When present, free phage-tail sheaths (usually "triggered") were almost always found adhering to and parallel with a flagellum (fig. 6), thus inducing neighbouring flagella to aggregate in a linear arrangement (fig. 7).

Because of these unexpected findings, we compared the features of representative $C$. jejuni and $C$. coli phages. The most common $C$. jejuni phage had a contractile tail and was usually found unattached to cells or wall fragments (fig. 8a). Its dimensions were: head diameter, $60-70 \mathrm{~nm}$; untriggered tail, $120-140 \mathrm{~nm} \times 16-22 \mathrm{~nm}$; triggered tail sheath, $50-60 \mathrm{~nm} \times 25-36 \mathrm{~nm}$; and needle, $120-140 \mathrm{~nm} \times 9-10 \mathrm{~nm}$. Measurement of the tail-sheath width was difficult because of an indistinct outer component (fig. $8 b$ ).

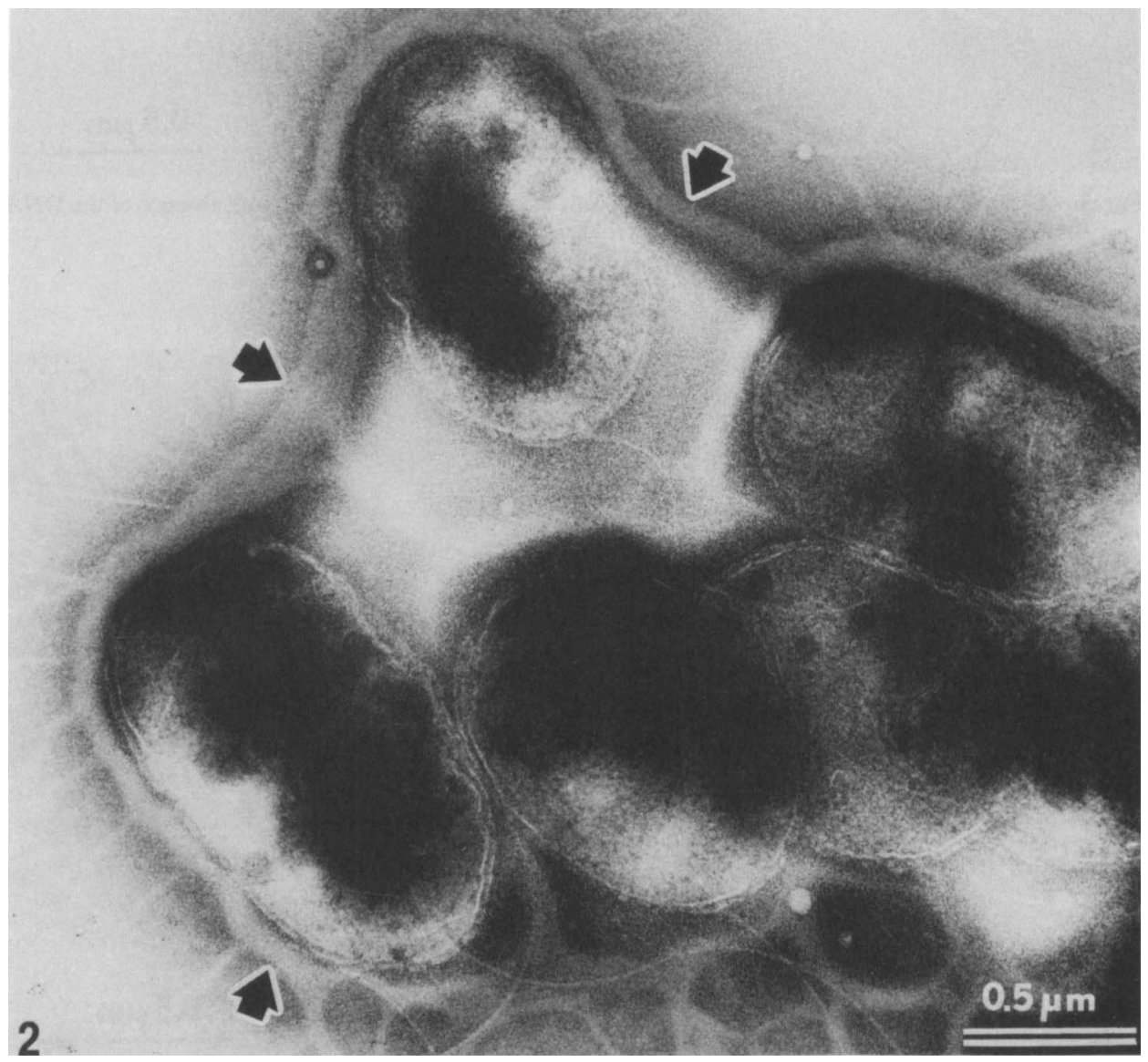

FIG. 2.-C. jejuni strain 1398. Auto-agglutinating cells with mantle of streaming amorphous DNA (arrowed); leakiness is indicated by intracellular accumulation of phosphotungstate. EM. 


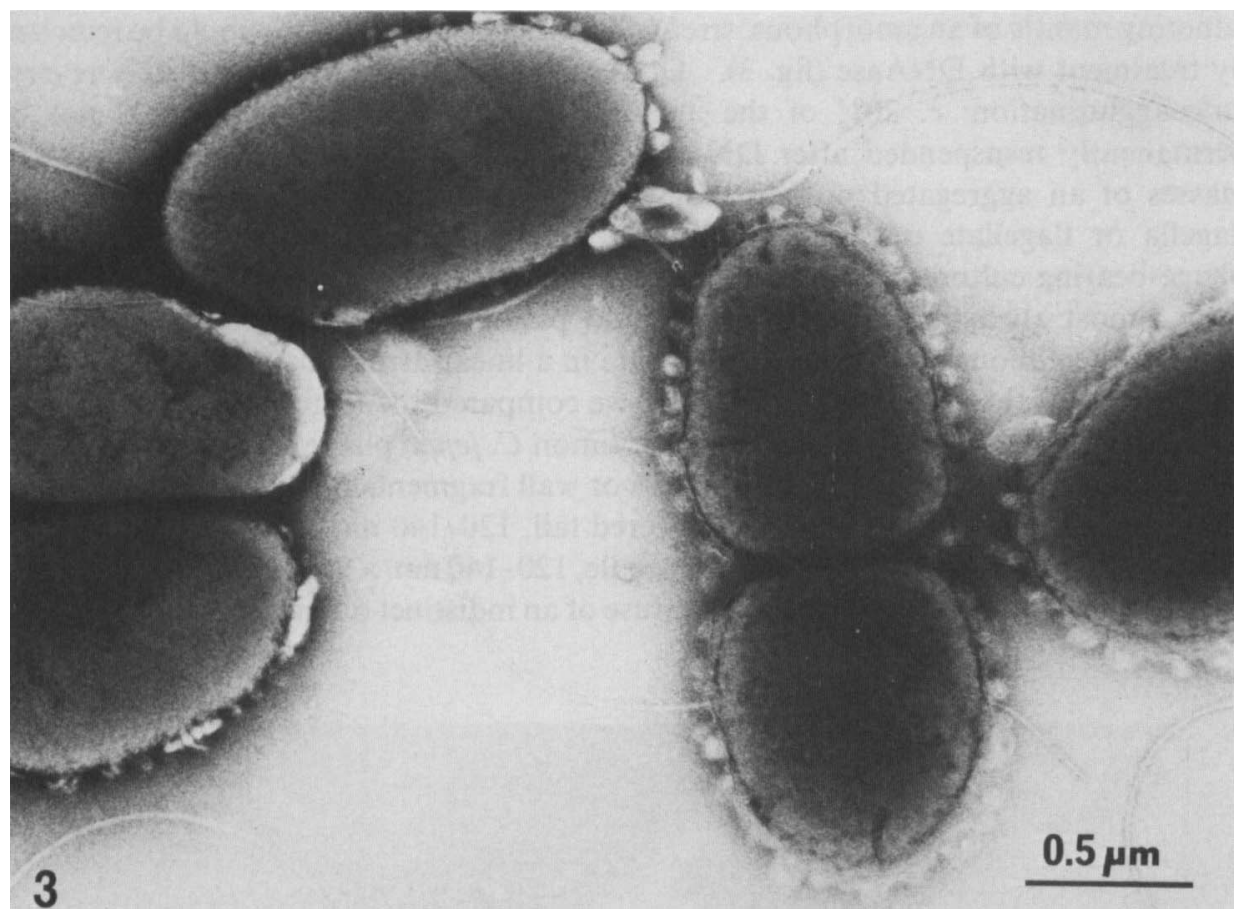

Fig. 3.-C. jejuni strain 917. Auto-agglutinating cells after DNAase treatment; note absence of the DNA mantle. EM.

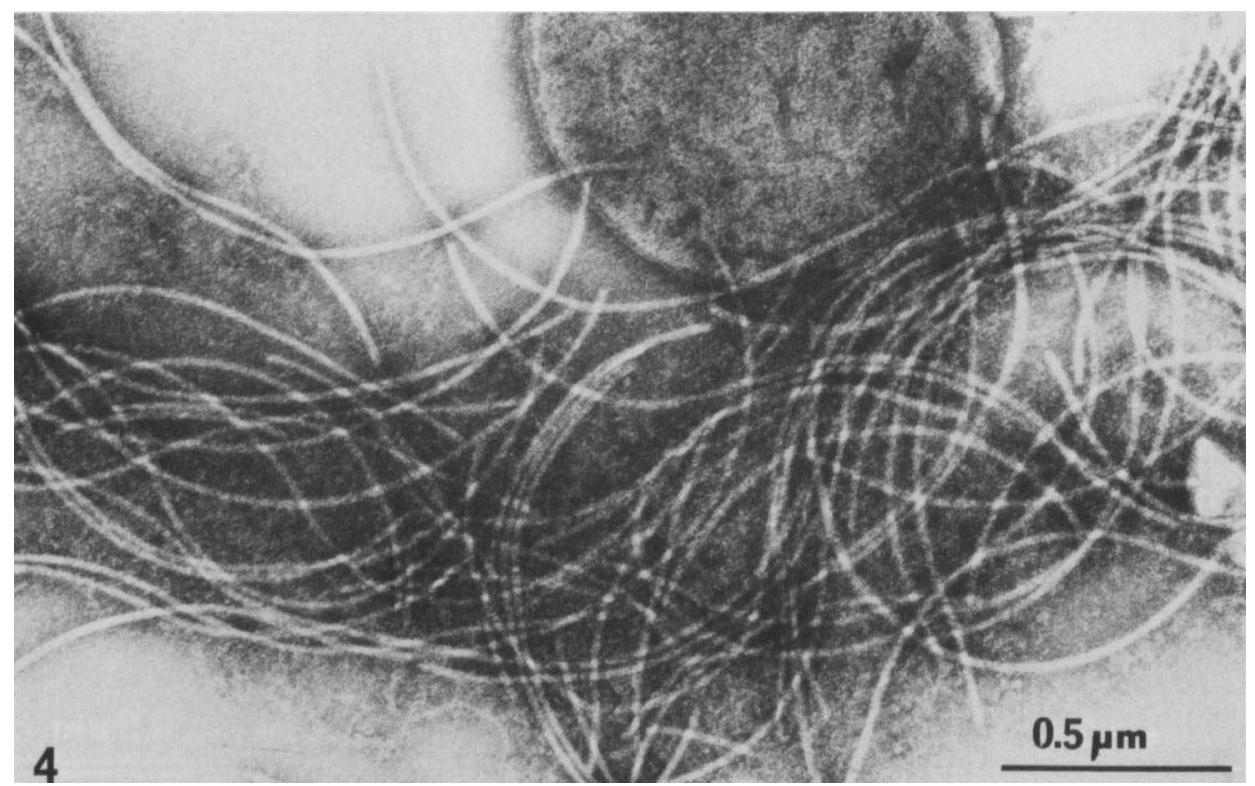

Fig. 4.-C. jejuni strain 958. Entangled agglutinated flagella commonly seen in phage-infected auto-agglutinating cultures. EM. 


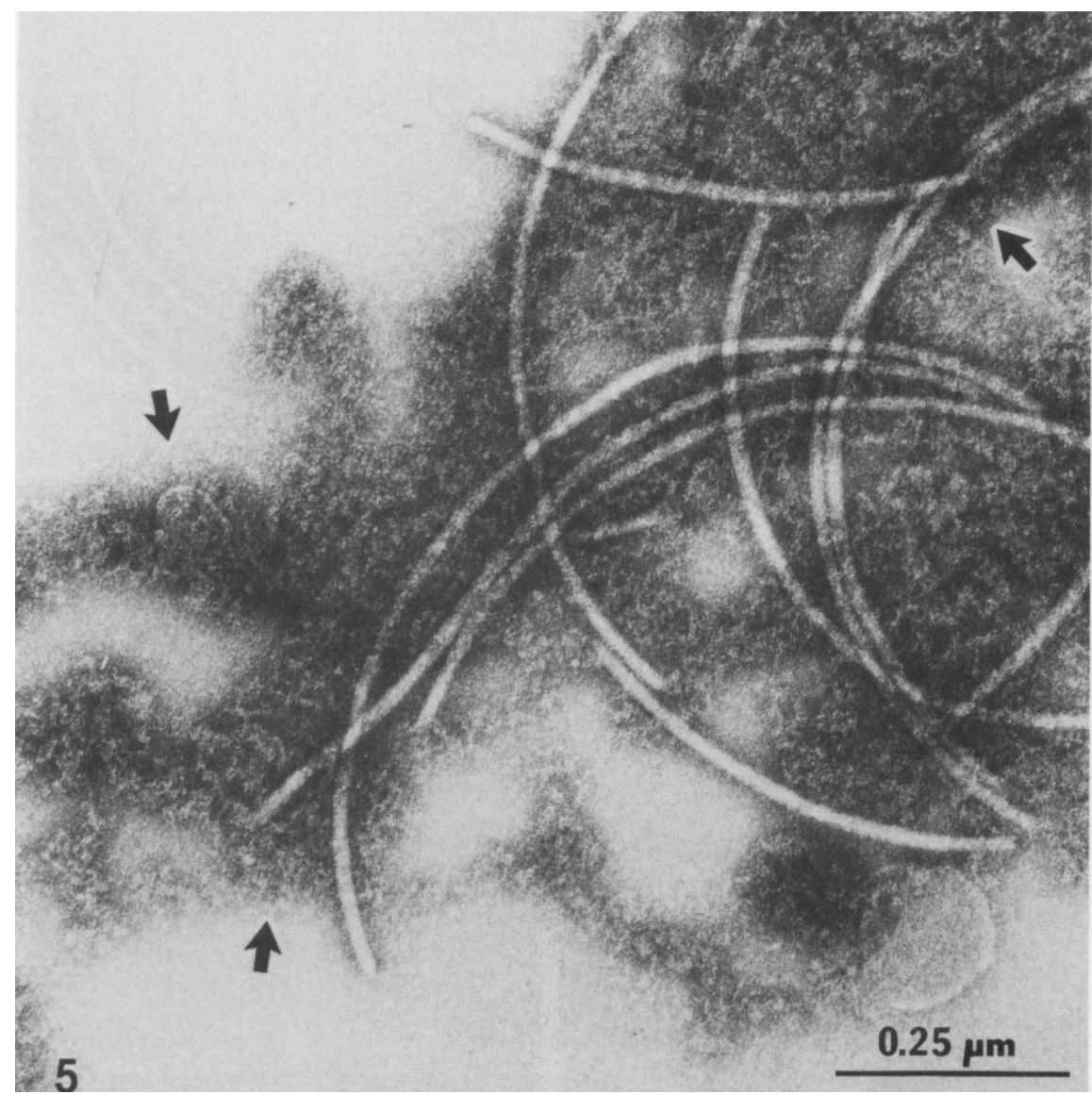

FIG. 5.-C. jejuni strain 958. Portion of a flagellar clump showing the aggregated protein (arrowed) presumed to induce agglutination. EM.

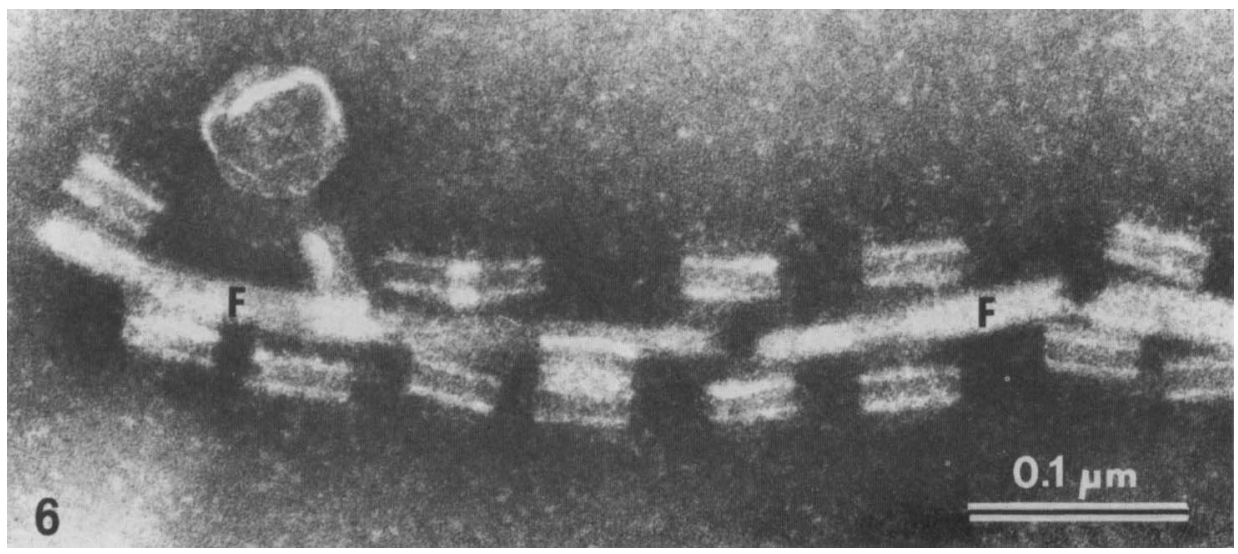

Fig. 6. - C. jejuni strain 958. Portion of a single flagellum (F) with parallel, adhering phage-tail sheaths; note the fibrous, indistinct bridging between the tail's outer layer and the flagellar surface. EM. 


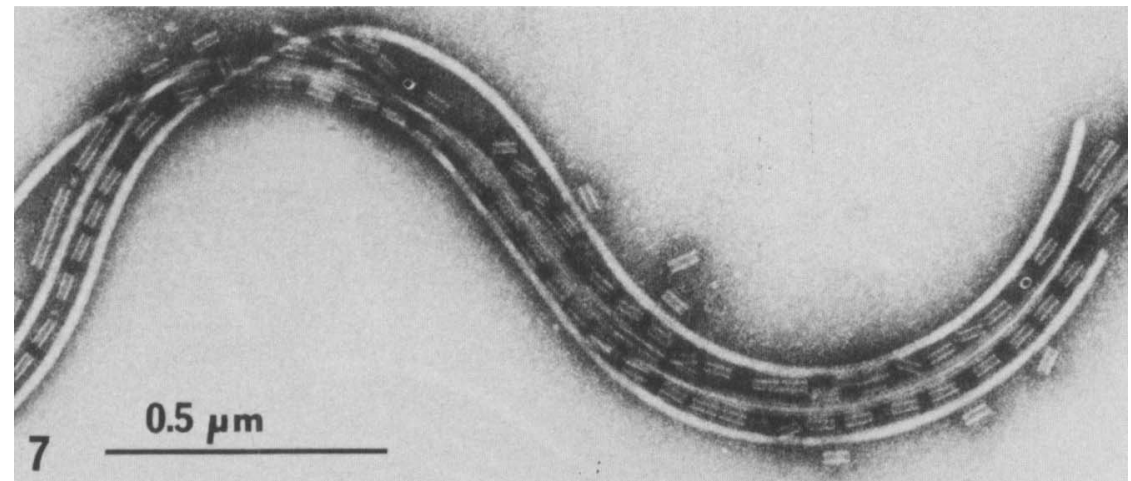

FIG. 7.-C. jejuni strain 958. Typical flagellar agglutination with numerous phage-tail sheaths attached to the flagellum. EM.
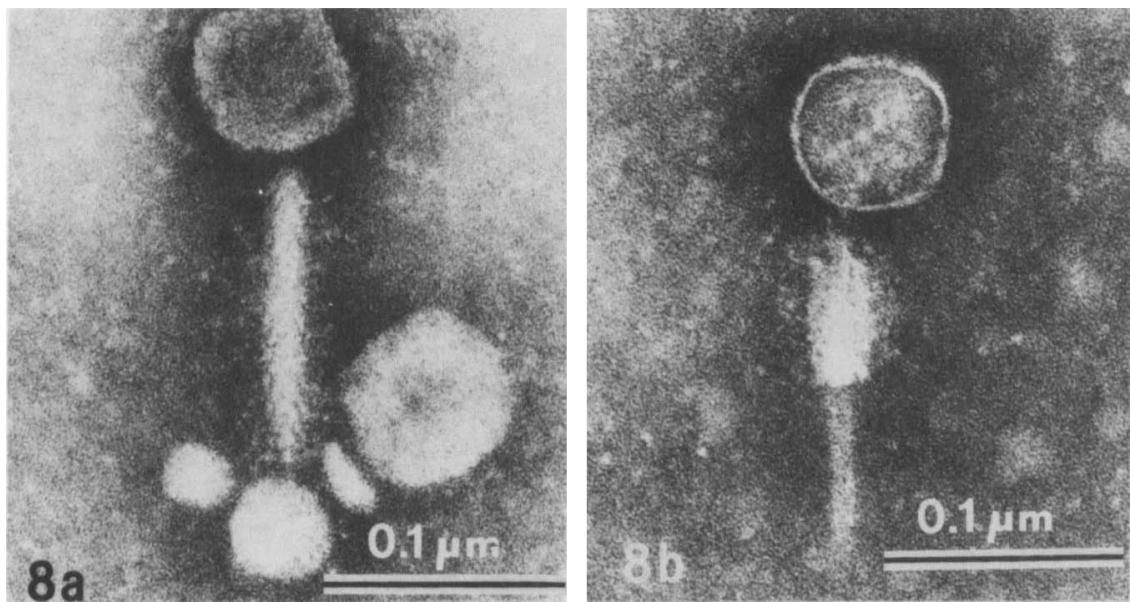

FIG. 8a and 8b.-C. jejuni strain 958. (a) Most common phage type with a contractile tail and isometric head; (b) triggered phage with empty head and indistinct outer-sheath layer. EM.
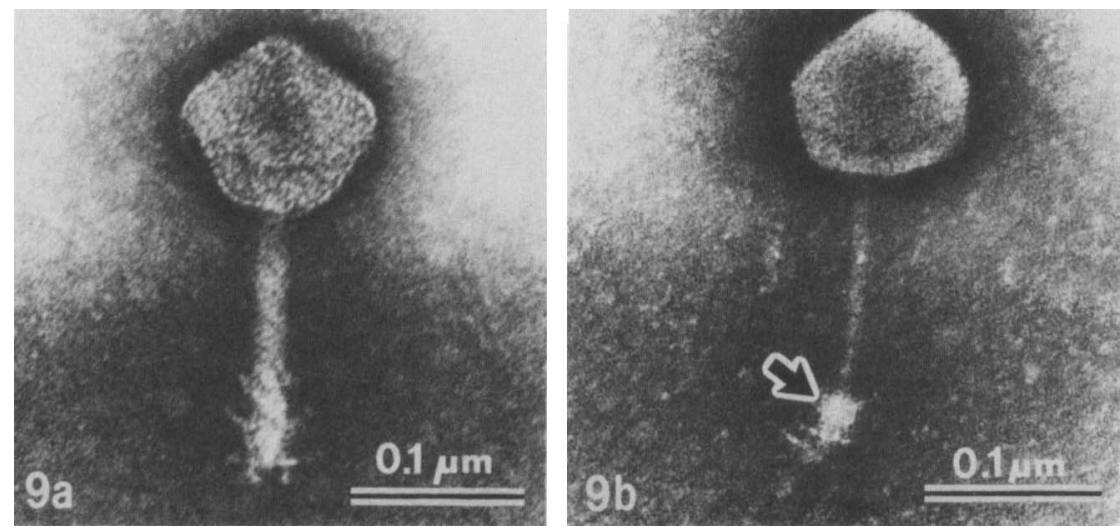

FIG. 9a and 9b.-C. coli strain 1491. (a) Typical intact phage with contractile tail; note knobby outer components at the tail's distal end. A similar phage was isolated from $C$. jejuni strain 1590 . (b) Phage lacking a tail sheath but showing a characteristic distal collet (arrowed). EM. 
Baseplate and tail-fibre assemblies were either absent or lacked sufficient structural integrity to be detected.

The $C$. coli phage examined in our study was from strains 1380 and 1491 ; it was similar to the contractile-tail type described by Fletcher (1965) but was larger and displayed a more angular head profile (fig. $9 a$ ) than the commonest $C$. jejuni phage. Its dimensions were: head diameter, $100-120 \mathrm{~nm}$; untriggered tail, $140-160 \mathrm{~nm} \times 18-21$ $\mathrm{nm}$; triggered tail sheath, $60-70 \mathrm{~nm} \times 28-33 \mathrm{~nm}$; and needle, $130-150 \mathrm{~nm} \times 9-11 \mathrm{~nm}$. Its baseplate and tail fibre assembly often had a large collet (fig. $9 b$ ). A phage isolated from $C$. jejuni strain 1590 was indistinguishable from the $C$. coli phage. By DIEM, none of its structural components appeared to share any antigens with the $C$. jejuni phage.

\section{Discussion}

Auto-agglutination appeared to be facilitated by three factors released from "leaky" or disrupted cells: (1) nascent DNA, (2) an adventitious aggregated protein, and (3) free phage-tail sheaths, when present. Extruded DNA accounted for most of the auto-agglutination in cultures in the stationary phase of growth because $c .80 \%$ of the agglutinated cells could be resuspended after DNAase treatment. The percentage of cells capable of being resuspended will probably vary from one auto-agglutinating culture to another, but our results support the rationale put forward by Lior et al. (1982) for their use of DNAase treatment, when necessary, in the slide agglutination test. The amount of extracellular DNA, and hence the extent of auto-agglutination, is probably controlled by the average cell age and by the activity of phages when present. The loop sampling method facilitated the detection of adhering DNA and the effects of digestion by DNAase. The adventitious aggregated protein associated with flagella probably represented a secondary auto-agglutinating factor. It may have accounted for the incomplete reversal of agglutination by DNAase. Because this protein was plentiful only in phage-infected cultures, we believe that it was a phage precursor. Free phage-tail sheaths, although uncommon in most cultures, had a striking affinity for the flagella. The parallel arrangement of the two structures was probably mediated by the sheaths' outer protein. The latter may have had as its unassembled precursor the adventitious aggregated protein. Fletcher (1965) observed an association of $C$. coli phage with flagella but the phage-tail sheath did not appear to be directly involved. Recognition of the three auto-agglutinating factors suggests that stable campylobacter suspensions for use in agglutination tests could be prepared from logarithmic-phase phage-free cultures.

Although $C$. fetus cultures do not auto-agglutinate, it is appropriate to summarise our observations on this species. None of the precipitating factors described here have been observed in $C$. fetus cultures, whether phage-infected or not. Phages of $C$. fetus lack a tail sheath (Bryner et al., 1973). This probably accounts for our inability to detect a protein with comparable flagellar affinity. The absence of adhering extracellular DNA is unexplained. However, we found that phage infection usually led to rapid and extensive lysis.

The taxonomic significance of our observation of a $C$. coli-type phage in $C$. jejuni strain 1590 has not been assessed. Restriction endonuclease analyses of the cellular and phage DNA might provide an insight into this interesting anomaly. 


\section{REFERENCES}

Berg, R. L., Jutila, J. W. AND Firehammer, B. D. 1971. A revised classification of Vibrio fetus. American Journal of Veterinary Research, 32, 11-22.

BRENNER, S. AND HORNE, R. W. 1959. A negative staining method for high resolution electron microscopy of viruses. Biochimica et Biophysica Acta, 34, 103-110.

BRYNER, J. H., Frank, A. H. AND O'BerRy, P. A. 1962. Dissociation studies of vibrios from the bovine genital tract. American Journal of Veterinary Research, 23, 32-41.

Bryner, J. H., RitchIE, A. E., Booth, G. D. AND Foley, J. W. 1973. Lytic activity of vibrio phages of strains of Vibrio fetus isolated from man and animals. Applied Microbiology, 26, $404-409$.

BryneR, J. H., Ritchie, A. E. AND Foley, J. W. 1982. Techniques for phage typing Campylobacter jejuni. In Campylobacter: epidemiology, pathogenesis and biochemistry, edited by D. G. Newell, MTP Press Ltd, Lancaster, p. 52.

BUTZLER, J. P. 1978. Infection with Campylobacters. In Modern topics in infection, edited by J. D. Williams, William Heinemann Medical Books, London, p. 214.

FLETCHER, R. D. 1965. Activity and morphology of Vibrio coli phage. American Journal of Veterinary Research, 26, 361-364.

Kosunen, T. U., Danielsson, D. AND KJellander, D. 1980. Serology of Campylobacter fetus ss. jejuni ("related" Campylobacters). Acta Pathologica et Microbiologica Scandinavica, B, 88, 207-218.

Lior, H., WoOdward, D. L., Edgar, J. A., Laroche, L. J. AND Gill, P. 1982. Serotyping of Campylobacter jejuni by slide agglutination based on heat-labile antigenic factors. Journal of Clinical Microbiology, 15, 761-768.

LUSSIER, G. 1962. Vibrionic dysentery of swine in Ontario. 2. Morphological, biochemical and serological characteristics of Vibrio coli. Canadian Veterinary Journal, 3, 267-278.

PEAD, P. J. 1979. Electron microscopy of Campylobacter jejuni. Journal of Medical Microbiology, 12, 383-385.

RitChIE, A. E., BRYNER, J. H. AND Foley, J. W. 1982. Auto-agglutination of Campylobacter jejuni: electron microscopic observations. In Campylobacter: epidemiology, pathogenesis and biochemistry, edited by D. G. Newell, MTP Press Ltd, Lancaster. p. 244.

RITCHIE, A. E. AND FERNELIUS, A. L. 1969. Characterization of bovine viral diarrhea viruses. V. Morphology of characteristic particles studied by electron microscopy. Archiv für die gesamte Virusforschung, 28, 369-389.

Ritchie, A. E., KEELER, R. F. AND BRYNER, J. H. 1966. Anatomical features of Vibrio fetus: electron microscopic survey. Journal of General Microbiology, 43, 427-438.

Skerman, V. B. D., McGowan, V. AND SNEATH, P. H. A. 1980 . Approved lists of bacterial names. International Journal of Systematic Bacteriology, 30, 225-420.

WERNER, H. J., LEVY, H. AND SPURLOCK, B. O. 1961. Electron microscopic observations of a mucoid strain of Vibrio fetus. American Journal of Veterinary Research, 22, 1121-1123. 